\title{
A Husserlian Approach to Aesthetic Experience: Existential Disinterest and Axiological Interest
}

\author{
Claudio Rozzoni* \\ IFILNOVA - New University of Lisbon \\ claudiorozzoni@fcsh.unl.pt
}

\begin{abstract}
As early as 1905 , Husserl made clear that, when it comes to aesthetic consideration, our "interest" is not directed toward the existence of the object as such, but rather toward the object's way of appearance. Husserl's famous letter to Hofmannsthal (1907) goes as far as to suggest that any existential concerns are potentially even a menace to the purity of aesthetic experience. This position clearly echoes Kant's account of aesthetic judgment presented in the third Critique, notably as regards the notion of disinterestedness. However, this is not tantamount to claiming that aesthetic attitude implies the suspension of all interest: this paper aims to show that it would be more appropriate to discuss it in terms of a change of interest: from an existential interest to an axiological one.
\end{abstract}

Keywords: Aesthetic Experience, Depiction, Value, Disinterestedness, Expression

\section{Depiction and aesthetic consideration}

In Husserl's analyses of imagination and image consciousness, the question of the aesthetic consideration of phenomena emerges intermittently. Significant examples of his interest in this theme can be found in Husserliana XXIII (henceforth Hua XXIII), the volume collecting Husserl's unpublished work on Phantasy, Image Consciousness and Memory. Husserl touches upon the topic in the very first text in this collection, albeit in a context prioritizing other

${ }^{*}$ https://orcid.org/0000-0002-3842-4568

ISSN: 0874-9493 (print) / ISSN-e: 2183-0142 (online)

DOI: $10.2478 /$ phainomenon-2019-0006

(C) 2019 Rozzoni. This is an open access article licensed under the Creative Commons Attribution-NonCommercial-NoDerivs License (http://creativecommons.org/licenses/by-nc$\mathrm{nd} / 3.0 /)$. 
problems - first and foremost that of defining the essential structures of phantasy and image consciousness.

Still, Appendix IX (from 1905) to this "Text No. 1" addresses aesthetic issues in a more specific way. Here, in context of discussing the nature of a photographic reproduction of Titian's Sacred and Profane Love, Husserl raises the issue of the role depiction plays in the artistic field. Clearly, looking at Titian's original painting is not the same as looking at a black and white photograph representing it. However, Husserl observes, even when encountering a representation of this work of art, one can look into the image and "immerse [him/her]self visually in" it as though viewing the Titian itself, thereby seeing the Sacred Love, the "glorious, superterrestrial female figure, and so on" (Husserl, 2005: 183).

Thus it seems that the subject, the sujet [Das Sujet] of a painting can also be seen in depictions of the original painting. As we shall see, this is possible through an aesthetic consciousness, "an entirely different consciousness than" (Husserl, 2005: 183) the one involved if the same depiction were to function as a representative for the painting, "point[ing] to the painting in which the same objects appear 'in different dimensions' and, above all, as colored" (Husserl, 2005: 178).

It is important to note that, in this instance, the necessity of defining the specific features brought in by aesthetic attitude led Husserl to introduce a distinction between an "inauthentic [eigentlich] representation" (Husserl, 2005: 183 ) and a representation wherein the "feeling of inauthenticity with respect to what is presented does not come up at all" (Husserl, 2005: 184); Husserl subsumes the former under the category of the depiction proper $^{1}$, while associating the latter with the moment of aesthetic consideration.

\footnotetext{
1 "These are inauthentic representations, though on the basis of images. The imaging consciousness is connected with intentions that refer to an object that is different from the object appearing in the image object and stands to it in certain characteristic relations, which, in addition, can serve to establish another representation, more direct and more authentic. We do best to say depictions, representation by means of more or less imperfect copies or depictions. (Hence copies of pictures belong here as well)" (Husserl, 2005: 183).
} 
In all likelihood, no one has seen all the original works depicted in the images they have viewed in catalogs or art history books. However, even in cases where one encounters only depictions (without seeing the works themselves), this does not prevent one from becoming familiar with the style expressed through those representations - and even being profoundly influenced by them. This simple remark alone may already suggest that, when viewing pictures in a catalog, one does not necessarily experience them as mere depictions, "images of" works at a museum, i.e., images that are by nature deficient compared to their corresponding originals. In such cases, what the observer experiences is not a consciousness of depiction or, in the terms used above, of an "inauthentic" representation. On the contrary, as we have seen, it is possible to "see the subject in the image" (see Husserl, 2005: 184); we may find the style expressed through the pictures to be attractive and admirable: we might absorb it and learn to recognize it. On the other hand, as regards the original Titian itself, Husserl asks rhetorically whether it is "a depictive being [ein Abbild-sein]" (Husserl, 2005: 183), whether its "subject is an object whose representant is the image understood as a depictive image, which is supposed to serve as the foundation for an inauthentic representation relating to it" (Husserl, 2005: 183-184, transl. modified).

In this regard, it is useful to recall that, at the time of his 1904/05 lectures on Phantasy and image consciousness, Husserl holds that experiencing a consciousness of image requires a "conflict [Widerstreit]" (Husserl, 2005: 32) between "image subject [Bildsujet]"-i.e., "the depicted object"—and "image object [Bildobjekt]"-i.e. "the appearing object that is the representant for the image subject" (Husserl, 2005: 20). Here, image consciousness [Bildbewusstsein] is still defined almost exclusively in terms of depiction consciousness [Abbildbewusstsein]. In the Ab-bildung construed this way, the particle $a b$ - seems to stand for an essential gap, for the indispensable distance between the image and the thing allowing the former to act as a "representant" for the latter.

For this very reason, we might suggest that, by definition, the depictive image proper is always lacking. In this respect, the $a b$ - of the Ab-bildung can also be understood has having a temporal connotation, in the sense that the copy imitating the original is that which has to come after. In a manner of speaking, the former chases the latter without ever truly reaching it - nor is it ever 
supposed to. Indeed, if that happened, the necessary contrast allowing one to draw a distinction between image and thing would ipso facto dissolve. Let us note that this is a theme dating back at least as far as Plato, who in his Cratylus (432b) pointed out that differences between a thing and its image were necessary in order for the latter to exist as such. As Plato famously put it, if the image of Cratylus would imitate Cratylus in every respect, we would no longer have Cratylus and his image, but rather two Cratyluses².

In other words, in the context of the image understood as depiction, one can always look for a "more authentic representation" that would be a worthier "representative" of the thing. However, the situation is different when it comes to the Titian painting discussed above, regarding which Husserl poses a question as simple as it is decisive: as regards "what is meant in aesthetic image-consciousness", would there be "another intuition" that might offer us "a more authentic representation of" it? (Husserl, 2005: 184, transl. modified). Once again, the question is evidently a rhetorical one. In fact, in the aesthetic attitude, having a representation of the object "from all sides" would not provide us a "more authentic representation". Indeed, our "interest" is not "directed toward the object as such, [...] but toward the object's exhibiting of itself in the image object" (Husserl, 2005: 184). To put it another way, we are focused not on what the image is lacking qua depiction, but in the specific manner of its manifestation.

In the aesthetic attitude, we are "interested" in the way the object is presented to us, in the way it "appears", in its "how" (wie) and not in its "what" (was): "Titian's picture represents to me sacred and profane love. From a definite standpoint. For this standpoint there is a representation such that $a$ feeling of inauthenticity with respect to what is presented does not come up at all. What interests me in this case is there; it is not indirectly represented" (Husserl, 2005: 184, italics mine). Keeping in mind our earlier remarks on the $a b$ - in Abbildung, we might affirm that, in the aesthetic regime, the necessary contrast for a depiction to be recognized, the essential distance pertaining to the depiction consciousness, is put out of action.

\footnotetext{
2 The same topos recurs in Descartes (see Descartes, 1996: 233). For a comparison between Plato and Descartes as regards this point, see Scholz (2004: 26-27) and Voltolini (2013: 26-29).
} 


\section{Existential disinterest}

On January 12, 1907, about two years after the course in Göttingen on Phantasy and image consciousness and his related observations on the Sacred Love, Husserl wrote a famous letter to Hugo von Hofmannsthal that was destined to become one of his best-known documents as regards his involvement with aesthetic issues. The Austrian poet had visited the philosopher in December 1906, while he was in Göttingen for a conference, and had presented Husserl with a literary gift, presumably his Kleine Dramen ${ }^{3}$. While formally conceived as a response to this gift, Husserl's letter soon becomes an opportunity for him ${ }^{4}$ to draw a comparison between the attitude of the phenomenologist and that of the artist - as well as that of the artist's audience, for as we shall see, Husserl begins the letter by considering the effects of Hofmannsthal's work on his readers. Within the confines of the conditions at hand (limited epistolary space, that is), Husserl tries to pin down some essential traits that he considers common to the phenomenological and artistic dimensions.

His "phenomenological method", he explains, "demands an attitude towards all forms of objectivity [...] which is closely related to the attitude and stance in which [Hofmannsthal's] art, as something purely aesthetic, places us", the audience, "with respect to the presented objects and the whole of the surrounding world" (Husserl, 2009: 2, italics mine). More specifically, the "intuition of a purely aesthetic work" entails a "suspension of all existential attitudes of the intellect and of all attitudes relating to emotions and the will which presuppose such an existential attitude". Better still, Husserl continues, in the case of the artistic experience this suspension is something to which we nearly passively surrender: we are "almost force[d] [...] into [...] a state of aesthetic intuition that excludes" any existential attitude (Husserl, 2009: 2). Husserl's point here appears to be clear: the relationship between existential concern and aesthetic purity is inversely proportional (see Husserl, 2009: 2).

\footnotetext{
${ }^{3}$ On Hofmannsthal's journey to Göttingen and the conference he held there entitled Der Dichter und diese Zeit — which Husserl was apparently able to attend — see Hirsch (1968: 108-111).

4 "What a hopeless and typical professor! He cannot even open his mouth, without giving a lecture" (Husserl, 2009: 2).
} 
The more one is concerned with the existence of what one is contemplating, the less one is open to pure aesthetic contemplation. In fact, according to this perspective, any existential concerns are potentially even a menace to the purity of aesthetic experience.

The parallel Husserl proposes between phenomenological and aesthetic attitudes is thus one grounded in such a suspension of the position-taking as regards the existence of objects that, in our natural attitude, we usually assume to be part of our reality. We have said that Husserl speaks of aesthetic attitude with respect to both the artist and the recipient. Like the phenomenologist, they experience reality as pure manifestation. However, nota bene, none of them deny the existence of what they experience, which would amount to taking a position against its existence. Rather, they experience what they experience as neutralized. Husserl's position clearly resonates with Kant's account of aesthetic judgement presented in the third Critique, notably as regards the notion of disinterestedness. Husserl points out that, in both phenomenological and aesthetic attitudes, one experiences the world as a pure appearance [Erscheinung]. The issue concerning the existence of the world is set aside; in this sense, one can rightly call phenomenological and artistic practices "disinterested". Even so, as we shall see, this is not tantamount to claiming that such practices imply the suspension of all interest; it would be more appropriate to discuss them in terms of a change of interest. Although they suspend any interest in the existence of the 'fact' world, the phenomenologist and the artist (as well as the recipient) are interested in the meaning that makes such a 'fact' possible, in its modes of manifestation ${ }^{5}$.

Despite these commonalities, of course, there are significant differences between the two as well. Husserl holds that the phenomenologist clearly "serves" no "purpose of aesthetic pleasure, but rather the purpose of continued investigations and cognition, and of constituting scientific insights in a new sphere (the philosophical sphere)" (Husserl, 2009: 2); the artist, meanwhile, "does not attempt to found the 'meaning' of the world-phenomenon and grasp

\footnotetext{
5 "Only one thing remains: to clarify, in a pure intuiting (in a pure intuiting analysis and abstraction), the meaning which is immanent in the pure phenomena, without ever going beyond them, i.e. without presupposing any transcendent existences that are intended in them" (Husserl, 2009: 2).
} 
it in concepts, but appropriates it intuitively, in order to gather, out if its plenitude, materials for the creation of aesthetic forms" (Husserl, 2009: 2). Unlike the philosopher, therefore, the artist works without concepts. Here, too, one can detect an implicit echo of Kant's third Critique, which is clearly reinforced when Husserl claims that the artist must possess "genius" and "follow, purely and solely, his daimonion" that "drives him to an intuiting-blind production" (Husserl, 2009: 2) —an intertwining of passivity and activity.

\section{Living in the appearing}

Significant insights for the development of this topic can also be found in an important Husserlian manuscript eloquently entitled "Aesthetics and phenomenology [Ästhetik und Phänomenologie]", preserved at the Husserl Archive in Louvain under the signature A VI $1^{6}$. This manuscript is relevant in that it sheds light on a point that is crucial to a deeper understanding of aesthetic experience - namely, that concerning its axiological dimension. Here, Husserl explicitly brings up the notions of value [Wert] and of Wertnehmen, a neologism he coins as a parallel to the German Wahrnehmen, "to perceive". As Husserl suggests in a passage from his 1907 Dingvorlesung, Wahrnehmen can be construed as a "taking as true [Für-wahr-Nehmen]"; Wertnehmen can analogously be understood to mean "taking as valuable [Für-wert-Nehmen]", with the corresponding substantive, Wertnehmung, thus implying "valuetaking" (see for example Husserl [2019: 307]).

More specifically, Ms. A VI 1 yields significant insights for a phenomenological account of aesthetic attitude in that it establishes an essential connection between the peculiar suspension of existence outlined above and the moment of value-taking. Indeed, Husserl writes that, in the aesthetic experience, we have: 1) a "value-taking [Wertnehmen]", whose correlate is an

\footnotetext{
${ }^{6}$ Ms. A VI 1 consists of 20 sheets composed (mostly) between 1906 and 1918, and likely compiled in August 1918. Three sheets of this manuscript are published in Hua XXIII: sheets 4 and 5 as Appendix LIX (probably 1916 or 1918) (Husserl, 2005: 651654) and sheet 12 as Appendix VI (probably 1906) (Husserl, 2005: 167-169). It is also worth recalling that sheet 7 is basically a sketch of the 1907 letter to Hofmannsthal. Sheets 8 and 9, on "Aesthetic objectivity [Ästhetische Objektivität]", were instead published in Scaramuzza and Schuhmann (1990).
} 
"aesthetic-axiological object" (and not an act of perceiving [Wahrnehmen], whose correlate would be an existent object); 2) peculiar feelings of the kind also mentioned in the letter to Hofmannsthal - that is, feelings not motivated by an existential stance: "delight in the beautiful [Freude am Schönen]" (see Ms. A VI $\left.1 / 2 \mathrm{a}^{7}\right)$.

However, as Husserl points out, once the relevance of these moments is brought out, what needs to be accounted for phenomenologically is the nature of their relationship, which is certainly a complicated one. For a start, while aesthetic values and feelings do not depend on the existence of the object, they are essentially related to its "way of appearance, in and for itself [Erscheinungsweise, an und für sich]" (see Ms. A VI 1/2a, here Husserl refers to Raphael's Madonna appearance in the same terms discussed above with respect to Titian's Sacred and Profane Love). Nevertheless, it is not that "in the aesthetic attitude", as Husserl underscores in the Ms. A VI 1 sheet on aesthetics, published as Appendix VI of Hua XXIII ${ }^{8}$, we turn appearance into an object (as would be the case "in the psychological attitude"). Nor, when aesthetically attuned, do we "make" appearance "into a theoretical object" or into a "practical" one, "tak[ing] delight [zu freuen] in it as something actual". Rather, aesthetic experience concerns "a pleasure [Gefallen]" that "leaves existence out of play and is essentially determined by the mode of appearance". Note that in conjunction with this statement, Husserl himself significantly adds: "see [...] Kant's theory" (Husserl, 2005: 168, note 6).

Yet even though the phenomenological attitude we have described thus far might be justifiably comprehended under the title of "aesthetic disinterestedness", it must be noted that, from a phenomenological perspective (as arguably already suggested by $\mathrm{Kant}^{9}$ ), aesthetic experience cannot merely

\footnotetext{
${ }^{7}$ I would like to thank the Husserl Archives in Leuven for permission to refer to and quote from Husserl's Nachlass.

${ }^{8}$ See above, note 6 .

${ }^{9}$ The specific and highly complex nature of the disinterest inherent in Kant's judgement of taste is well beyond the scope of this article. For our purposes, suffice it to recall that Kant, too, spoke in this context not of disinterest lato sensu, but rather of disinterest in the existence of the object under consideration. For a discussion of seminal issues concerning Kantian disinterest, see for example Guyer, 1978. For a discussion of Kantian aesthetic disinterestedness from Nietzsche's point of view and its difference
} 
be defined as a disinterested tout court-this disinterest is specifically in reference to the real existence of the object under contemplation. To clarify this point, it is useful to point out that in the section on "aesthetics" quoted above, Husserl distinguishes between "interest in the thing [Interesse an der Sache]" (Husserl, 2005: 168, transl. modified) - interest concerning its existence, that is-from "interest in the appearance" (Husserl, 2005: 168), which is the decisive factor in aesthetic experience.

It is also worth noting that "aesthetic consciousness is not restricted to works of art" (Brough, 2005: xlix) ${ }^{10}$. Clearly, "artistic" and "aesthetic" are not synonymous adjectives. Even in a "drawing-room", Husserl writes, "different appearances of the same object", "the disposition of vases, ashtrays, and so forth", cannot be said to be "equivalent" in aesthetic feeling (Husserl, 2005: 168 ). What is at stake here is the possibility of arousing pleasure through the mode of manifestation of pure phenomena, without regard to their real being.

However, another point must be stressed with regard to disinterest "in the thing": even though, in the aesthetic experience, our interest is not directed towards the object in its concrete actuality, that does not automatically mean that the "function of the object, its purposes, and so on" must be hidden or denied. Rather, Husserl argues that such functions and purposes "are coexcited, they must be there in clear fashion" in order to avoid the emergence of a "conflict between the form of the object and its function" (Husserl, 2005: 168). In the following passage, he develops this insight using the example of "the presentation of human beings" (Husserl, 2005: 169), uncovering at least two aspects that I consider particularly relevant for an analysis concerning a phenomenology of aesthetic value:

from other forms of aesthetic disinterestedness (notably Schopenhauer's), see also Constâncio, 2017.

10 "It can also occur in the contemplation of an object in nature, such as a mountain (648) or a landscape (615). It can even occur in the case of something I phantasy (649). The essential point about aesthetic consciousness is that the object that gives me aesthetic delight, whatever that object may be, does so because of the way in which it appears (462, 522)" (Brough, 2005: xlix). Bracketed numbers in this quotation refer to passages found in Husserl (2005). 
Groups. Not masses of human bodily members, in the presence of which one would not really know where or to what the members belong. To which head do these legs, these arms, and so on, belong? What is she doing, where is he standing? Characteristic position. Instant photography: Among the innumerable particular positions that actually occur, which is the one "noticed"? And among those that are noticed, which is the "best"? Every nerve, every muscle, attuned to the action. Nothing indifferent, nothing random. Etc. As much expression as possible; that is to say: the excitation with the greatest possible wealth of appearance, the most powerful and most intuitive excitation possible of the consciousness of the object-specifically, not of the "human being" as a physical thing but of the human being in its function, in its activity (a pugilist), in its doing and suffering, which is supposed to be precisely the object of presentation. With as much unity as possible. The pugilist can, of course, simultaneously have a stomachache, and the gripes can express themselves in his grimace. Now that would be a beautiful aesthetic object: A pugilist or discus thrower who simultaneously has a stomachache (Husserl, 2005: 169, italics mine).

The first aspect I would like to highlight is the emphasis Husserl put here on the term "expression [Ausdruck]". Significantly, in a note in the margins of this passage, he underscores the key role that "expression" plays in the emergence of the aesthetic feeling, as well as its essential connection with the way of appearance. He stresses that "the 'things', that is, the thing appearances, always express something" while crucially specifying that "they do not do this in the manner of an empty sign. They always express from within" (Husserl, 2005: 169 , note 7 , italics mine). What is outlined here is the idea of a 'scale of aesthetic expressivity', according to which one see things as more or less beautiful or ugly (see Husserl, 2005: 169). The best aesthetic effect - the most beautiful - corresponds to the maximum amount of expression, while "what

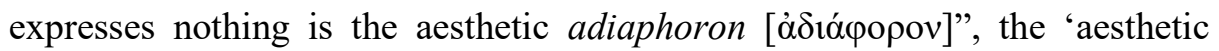
indifferent', the 'degree zero of aestheticity' ${ }^{11}$.

Second, I would like to stress the reference to the expressive "characteristic position" that can be offered, for instance, by an "instant photograph". The

${ }^{11}$ For a discussion of this important passage on "expression", see also Rodrigo (2009: 103-105). 
choice of the 'right' moment, of the "pregnant instant" (recalling the DiderotLessing idea ${ }^{12}$ ), concerns the search for an image that, rather than needing to look like reality in terms of shared moments (color, shape) and depictive relationships (with a subject external to the image), needs to express something "from within", untouched by all existential concern: an action, a tension, a feeling, an atmosphere, a force. In other words, the expressed moment cannot be reduced to the factual components we actually perceive ${ }^{13}$ : the quality of the expressed is not concerned with the belief in the existence of what expresses $\mathrm{it}^{14}$. And yet, at the same time, what is expressed cannot be construed as something independent from what expresses it (Cometti, 2002: 79).

Thus, to sum up, we might put Husserl's point this way: aesthetic experience, which can emerge in relation to both what we call perceptive reality and the dimension of inactual (artistic or non-artistic) presentification, focuses on the mode of appearance. This attitude, as Husserl explains in his letter to Hofmannsthal ${ }^{15}$, puts out of action the interest in the actual existence of the source of pleasure. We become interested in the object because of its capacity for expression, and this potentiality can work independently of our belief (or non-belief) in its existence ${ }^{16}$. To return to the terms introduced above, the $a b$ -

12 On this "pregnant moment" or "pregnant instant", all along these DiderotianLessingian lines, see also Barthes (1977: 173), and Barthes (2011: 107).

13 "With regard to the expressivity of a face one can say that it presents a specific quality that does not simply reside in individual features, just as the expressive qualities of a melody do not reside in the sum of notes belonging to a given musical sequence" (Cometti, 2002: 74). More generally, see Cometti (2002) for a productive attempt to conciliate Merleau-Ponty's and Wittgenstein's positions on expression.

14 "The expression of soul in a face. One really needs to remember that a face with a soulful expression can be painted, in order to believe that it is merely shapes and colours that make this impression. It isn't to be believed, that it is merely the eyeseyeball, lids, eyelashes etc. - of a human being, that one can be lost in the gaze of, into which one can look with astonishment and delight. And yet human eyes just do affect one like this" (Wittgenstein, 1980: 54, § 267).

${ }^{15}$ See also the emphasis put on this point in later remarks (25/12/1931) found in Husserl (2002: 370).

${ }^{16}$ See also Appendix XL of Hua XXIII (to No. 15c and d): 521: "Let us consider aesthetic contemplation [...]. In this case, "the taking of a position in relation to being or nonbeing is excluded. That is not what is at stake". 
of the Abbildung becomes irrelevant from the perspective of expression. What counts as expressive is instead the poetic (poiesis), shaping, power of the Bildung.

In this context, then, it becomes clear why we can claim that aesthetic experiences involve not annulled interest, but shifting interest - a qualitative shift. We do not live in the object itself, taking it as something existent; rather, we "live in the appearing", as Husserl states in another 1912 manuscript (Husserl, 2005: 521). Our interest shifts from the existential 'what' to the aesthetic 'how'. Further light is shed on this intricate nexus through Text no. $15 h$ (probably 1912) of Hua XXIII, which is devoted to the "aesthetic consciousness": once again, the primary focus of the text is on the intimate relationship between the aesthetic and the axiological-emotional dimensions: "the manner of appearing is the bearer of aesthetic feeling-characteristics" (Husserl, 2005: 462). More precisely, here Husserl specifies that "aesthetic valuation [ästhetische Wertung] is essentially connected with the distinction [Unterschied] between the consciousness of an object as such and the object's manner of appearing" (Husserl, 2005: 461).

We previously asserted that the object is not irrelevant to aesthetic experience; here, Husserl reaffirms that the aesthetic feeling is directed at the appearance itself, rather than at the object "through the appearance". He also remarks that this is not tantamount to claiming that the object-with all its connections - shrinks into insignificance. The aesthetic feeling is concerned with "the object" as well, albeit "only 'for the sake of the appearance" (Husserl, 2005: 464). Specifically, there is a sort of "turning back [Rückwendung]" of the subject toward the manner of appearance, a folding of the focus from the "what" onto the "how" and vice versa ${ }^{17}$, creating a dynamic equilibrium between object and appearance: "The appearance is the appearance of the object; the object is the object in the appearance" (Husserl, 2005: 462). And the aesthetic feeling arises from this very oscillation, this back and forth movement towards the object's way of appearance, "in the shift from the focus

\footnotetext{
${ }^{17}$ Marc Richir previously emphasized this aspect in his important commentary on Text no. $15 h$ of Hua XXIII. See Richir (1999).
} 
on the object to this reflective focus and vice versa" (Husserl, 2005: 464, italics mine).

This "turning back", this 'folding', can then be dynamically understood as a "reflective" movement that-in Kantian terms-never finds a concept capable of circumscribing it. This is a 'circular' movement whereby the aesthetic object becomes both "origin" and "term" of the feeling without the dynamism of this movement ever being locked up in the static nature of a concept $^{18}$. And such a "turning back", in principle, can occur for any object, since "however displeasing" the object "may be in itself, however negatively I may value it, receives an aesthetic coloration because of its manner of appearing" (Husserl, 2005: 462).

\section{Axiological interest}

This shift of interest opens up another crucial issue: the question of whether or not such an apositional attitude (apositional as regards existence, that is, "neutral") involves another sort of position-taking, namely an axiological position-taking carried out in terms of the previously mentioned "value-taking [Wertnehmung]".

Husserl seems to suggest that this is the case. In Appendix XL (from 1912), quoted above ${ }^{19}$, although he does reassert that we "do not [...] carry out any position taking with respect to what appears" in aesthetic experience, he also states that we have an "aesthetic position taking that belongs to feeling" (Husserl, 2005: 521) inherent to the sphere of value - in other words, we "carry out" an "aesthetic valuing" (Husserl, 2005: 522). In another research manuscript from Hua XXIII-Appendix LVIII, likely dated 1917, "on the

\footnotetext{
18 'It is not the same to say 'there is a square table in the room' and 'in the same room there is a beautiful table'. In this last example [...] the statement assumes someone's aesthetic point of view. [...] The aesthetic object, to use the Kantian terms of the Critique of the Power of Judgment, is the occasion (the origin) but also the term of a feeling, of an emotional-affective timbre of perceiving, of a subjective reflection, that is, of an aesthetic reflection in perceiving itself" (Desideri, 2004: 34). Yet, "with the caveat that outside of this pleasure - of this internal reflection of perceptive life in a pure feeling (of pleasure or displeasure) - the aesthetic object is in a state of latency: of pure possibility" (Desideri, 2004: 37, my translation).

${ }^{19}$ See above, note 16 .
} 
theory of depiction"- -after having remarked that the depiction aesthetically considered "concerns what is presented only with respect to the moments (and the How of the moments) presented", he asks: "Is it the case that I am not interested in existence here? To what extent am I not interested in it? I am not interested in the existence of what is presented per se. But I am interested in the existence of the ideal presentation of what is presented, in which case the positing of the existence of what is presented, if it occurs at all, plays no role in the consciousness of its value" (Husserl, 2005: 647, italics mine).

It thus seems that, in the aesthetic experience, we grasp beauty felt as a value. Husserl refers to "the object of the beauty-evaluation [Schön-Wertung]" (Husserl, 2005: 649) as an "ideal" object that, while not being affected by existential positions, is nonetheless given through a position-taking: the value is posited, and yet neutral as regards the different "modalizations" (see for example Husserl, 2005: 544) concerning any existential claim.

Indeed, "if the actual object were to turn into a semblance object and consequently the actual mode of appearance into an inactual mode of appearance (hence one not existing in its stratum of being either)", this would not change the fact that "we would then nevertheless have something beautiful that exists, a mere figment, an 'image': which is precisely an ideal object and not a 'real' object (in which case we comprehend the actual modes of appearance themselves under the title of what is real)" (Husserl, 2005: 649, italics mine). Although proposing an intimate relation between the expressive and axiological dimensions of aesthetic experience would obviously raise more questions that can be addressed here, recalling the above passage on expression and aesthetic contemplation, we might suggest that in the "aesthetic valuation [ästhetische Wertung]" such an "ideality" is what is expressed through the way of appearance, neutral as regards issues concerning the "attachment" of the modes of appearance "to actual subjects (and to subjects projected into the world by phantasy), and mediately to natural space and natural time and the natural world itself" (Husserl, 2005: 649).

Moreover, in keeping with what we said above about the irreducibility of the expressed to the actual appearances expressing it, here Husserl affirms that 
the "beauty-value" cannot be reduced to the way of appearance in itself $\mathrm{f}^{20}$. What is grasped as a value is an ideality that can be presented through other manifestations, through other variations of the 'first' appearance (which is then first only from a chronological — but not ideal — point of view), since "the value remains for me even if I no longer have the respective semblance; if I can reproduce the semblance through memory or fiction, then I have it again, enjoy it again, although the re-presentation may not produce its full givenness" (Husserl, 2005: 649).

All the aspects we have considered up to this point find an important reformulation in First Philosophy, the seminal lecture course Husserl taught in the Winter Semester of 1923/24 at the University of Freiburg. This is a text of great significance: Husserl "composed" it "to serve as the basis for his repeatedly planned but never completed 'Systematic Work' that would introduce and summarize his mature thought" (Luft, 2019: xiii), and even though it did not see the light of day within Husserl's lifetime, he repeatedly expressed intentions to publish it (see Luft, 2019: xiii-xiv). Of particular relevance in this context is "Part Two: Theory of the Phenomenological Reduction", which Husserl taught in the second half of the winter semester, and which was posthumously published in 1959 in Volume VIII of Husserliana. It might be suggested that, here, many years after his letter to Hofmannsthal, Husserl once again draws a parallel between philosophical and artistic (aesthetic) attitudes - though this treatment of the topic is clearly in the context of a broader and more mature development ${ }^{21}$, one drawing upon some of the most substantial results obtained through the manuscripts discussed above. Indeed, Husserl characterizes the artistic/aesthetic experience of the subject in terms of an intimate connection between value and feeling.

Husserl concluded his 1907 letter with a post scriptum listing the "three golden rules for the artist (in the widest sense), which at the same time are the

\footnotetext{
20 "It must be observed here that the beauty-value in question does not lie in the mode of appearance that I am having impressionally and that I enjoy while I am having it. Enjoyed value is not value itself, which can exist without being enjoyed" (Husserl, 2005: 49).

${ }^{21}$ Such a treatment can be said to "spread over' "Section Three" of this "Part Two" on the "Theory of the Phenomenological Reduction". See Husserl (2019: 286-333).
} 
public secrets of all true greatness" (Husserl, 2009: 2). One of these, as mentioned, claims that the artist has to "follow, purely and solely, his daimonion", which "drives him to an intuiting-blind production" (Husserl, 2009: 2). Thus, it is highly significant that, in First Philosophy, this very "intuiting-blind" dimension is developed through the notion of value, more

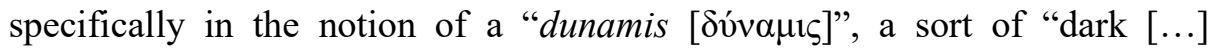
purposive idea" that "must hold valid for me" (Husserl, 2019: 303-304). The artist works to shape this valuable "dark idea" through "pleasure" (moment of approval) and "displeasure" (moment of rejection) (Husserl, 2019: 304). Again, this validity is something that must originally manifest as felt, since the aesthetic attitude is that of feeling ${ }^{22}$ - once again echoing the Kantian third Critique.

These pages also offer a more clearly articulated formulation of the critical relationship between interest and disinterest in the aesthetic dimension-what one might call 'disinterested interest'. The key features here are that of "interest of the heart [Gemütsinteresse], a valuing interest [wertendes Interesse] in the broadest sense of the term" (Husserl, 2019: 307), and the characterization of this value as the theme of aesthetic intention. Significantly, the difference between existential and heart (Gemüt) interests correlates to the one introduced above between Wahrnehmung as "taking as true [Für-wahr-Nehmen]" and Wertnehmung as "value-taking", which Husserl restates here as follows: "the value itself in its value-truth [Wertwahrheit] is not perceived [wahrgenommen], but as it were taken as value; and what perception [Wahrnehmung] achieves for the mere object, is achieved for the value by value-taking [Wertnehmung]" (Husserl, 2019: 307) 23.

As mentioned, while not entailing any perception proper, our artistic experience can be said to imply a positional-axiological — dimension. Again, this applies to the artist as well as the spectator, i.e., "the aesthetic contemplator" who "lives in a valuing interest" (Husserl, 2019: 308), that is, in

\footnotetext{
${ }^{22}$ For this reason, Husserl suggests that, properly speaking, it cannot be claimed that an "art historian" operates in an aesthetic attitude, since he/she switches into a theoretical one (see for example Husserl, 2019: 304 and 308).

${ }^{23}$ On this parallel between the two forms of position-taking, see also Husserl (1989: 10-11).
} 
an "interest of the heart". As Husserl puts it, art can cause us to experience value as a telos holding the productive power of an attractive dunamis: the aesthetic subject is driven by it, "wants to fulfill within itself, in the mode of the full and pure artistic pleasure [...], the aesthetic object as this concrete value in itself", and the object felt in the "pure and sated artistic pleasure" is "energeia

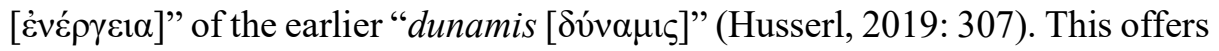
a more specific explanation of the sense in which, within an aesthetic experience, we can still be said to be "interested" despite our lack of interest in the existence or non-existence of what we are experiencing. It also reaffirms that our ability to "take value" from an object's manner of appearance is essentially unaffected by its actual existence or non-existence: in principle, aesthetic value can be expressed equally through reality and phantasy, through objects "in the flesh" just as much as through images.

To touch briefly upon an issue that seems to warrant further development: art can aesthetically open up or express a horizon of values - whether aesthetic or not - in ways that can, in turn, expand our scope of axiological interest. It is not a matter of merely conveying existing values aesthetically. Rather, art offers original presentations of emotional teloi as values that "attract the subject [...] insofar as the self feels [them] as something concerning itself emotionally" (Costa, 2014: 140, my translation). This is clearly another way in which arteven when 'enjoyed' in the neutrality of an experience 'at a distance' - can come to interest us directly, influencing our conceptions of what we call the 'real world' 24 .

${ }^{24}$ See, for example, Robert Pippin's insightful discussion of these axiological possibilities from the perspective of the Dardenne brothers' cinematic thought: "I will claim that various cinematic properties of their films involve ways of rethinking and challenging basic issues in our conventional understanding of the relation between agent and deed in ordinary action and in action explanation, and so they intimate an unusual picture of human subjectivity" (Pippin, 2015: 758). 


\section{Bibliography}

BARTHES, R. (2011). The Preparation of the Novel: Lecture Courses and Seminars at the Collège de France (1978-1979 and 1979-1980), New York: Columbia University Press.

— (1977). «Diderot, Brecht, Eisenstein (1973)». In: R. Barthes, Image Music - Text, London: Fontana Press, 69-78.

BROUGH, J. (2005). «Translator's introduction». In: E. Husserl (Ed.), Phantasy, Image Consciousness and Memory (1898-1925), Dordrecht: Springer, xxixlxviii.

CometTI, J.-P. (2002). «Merleau-Ponty, Wittgenstein, and the Question of Expression». Revue internationale de philosophie, 1: 73-89.

CONSTÂNCIO, J.M.P. (2017). «Who is right, Kant or Stendhal?: On Nietzsche's Kantian Critique of Kant's Aesthetics». In: M.J.M. Branco and K. Hay (eds.), Nietzsche and Kant on Aesthetics and Anthropology. London: Bloomsbury, 63-98.

Costa, V. (2014). Verso una fenomenologia delle tonalità emotive. In: G. Matteucci and M. Portera (eds.), La natura delle emozioni, Milano: Mimesis, 129-143.

Descartes, R. (1996). La Dioptrique (1637). In: Id., CEuvres de Descartes, Paris: Cerf, 1897-1909, rééd. Paris: Vrin-CNRS, 11 vol., t. VI.

DESIDERI, F. (2004). Forme dell'estetica. Dall'esperienza del bello al problema dell'arte, Roma-Bari: Laterza.

GUYER, P. (1978). «Disinterestedness and Desire in Kant's Aesthetics». The Journal of Aesthetics and Art Criticism, 36/4: 449-460.

HIRSCH, R. (1968). «Edmund Husserl und Hugo von Hofmannsthal: eine Begegnung und ein Brief». In: C.-J. Friedrich and B. Reifenberg (eds.), Sprache und Politik. Festgabe für Dolf Sternberger zum sechzigsten Geburtstag, Heidelberg: Verlag Lambert Schneider, 108-115.

Husserl, E. (2019). First Philosophy. Lectures 1923/24 and Related Texts from the Manuscripts (1920-1925), Dordrecht: Springer.

— (2009). «Letter to Hofmannsthal (1907)». Site, 26-27: 2.

- (2005). Phantasy, Image Consciousness and Memory (1898-1925), Dordrecht: Springer.

- (2002). Zur phänomenologischen Reduktion. Texte aus dem Nachlass (19261935), Dordrecht: Kluwer.

- (1989). Ideas Pertaining to a Pure Phenomenology and to Phenomenological Philosophy, Second Book, Dordrecht: Kluwer. 
LUFT, S. (2019). «Introduction to the translation». In: E. Husserl, First Philosophy. Lectures 1923/24 and Related Texts from the Manuscripts (1920-1925), Dordrecht: Springer, xiii- 1xxxv.

PIPPIN, R. (2015). «Psychology Degree Zero? The Representation of Action in the Films of the Dardenne Brothers». Critical Inquiry, 41/4: 757-785.

RICHIR, M. (1999). "Commentaire de Phénoménologie de la conscience esthétique de Husserl». Revue d'Esthétique (Esthétique et phénoménologie), 36: $15-23$.

Rodrigo, P. (2009). L'intentionnalité créatrice. Problèmes de phénoménologie et d'esthétique, Paris: Vrin.

SCARAMUZZA, G. and SCHUHMANN, K. (1990). «Ein Husserlmanuskript über Ästhetik». Husserl Studies, 7/3: 165-177.

Scholz, O. R. (2004). Bild, Darstellung, Zeichen. Philosophische Theorien bildlicher Darstellung, Frankfurt am Main: Klostermann.

VolTOLINI, A. (2013). Immagine, Bologna: Il Mulino.

Wittgenstein, L. (1980). Remarks on the Philosophy of Psychology, vol. I, Oxford: Basil Blackwell.

Claudio Rozzoni obtained his Ph.D. in Aesthetics and Theory of Art from the University of Palermo with a dissertation on Marcel Proust and philosophy. He then developed two post-doctoral research programs about the notion of image at the University of Milan (the first starting from both Husserl's and Fink's works, while the second dealing with Diderot's Salons). In 2011 he was awarded the New Aesthetics Prize by Società Italiana d'Estetica (SIE). He is currently a researcher at the IFILNOVA of the New University of Lisbon, with a project focusing on "Aesthetic Experience, Values, Emotions in the Contemporary Lifeworld". He was a Visiting Scholar at the Husserl-Archive of the Universität zu Köln (2013) and at UCLA (University of California, Los Angeles), Department of Film, Television and Digital Media (2015), as well as a Visiting Professor at the University of Milan (2017-2018). 